\title{
Brief on Behalf of the National Black Law Students Association as Amicus Curiae in Buck v. Davis
}

\author{
Aderson Francois \\ Deborah N. Archer \\ New York Law School, deborah.archer@nyls.edu \\ Daniel Warshawsky \\ New York Law School
}

Follow this and additional works at: https://digitalcommons.nyls.edu/fac_other_pubs

Part of the Criminal Law Commons, and the Law and Race Commons

\section{Recommended Citation}

Francois, Aderson; Archer, Deborah N.; and Warshawsky, Daniel, "Brief on Behalf of the National Black Law Students Association as Amicus Curiae in Buck v. Davis" (2017). Other Publications. 165.

https://digitalcommons.nyls.edu/fac_other_pubs/165 
No. 15-8049

\title{
Jy $\mathfrak{n}$ the Supreme Court of the ânited States
}

\author{
DUANE EDWARD BUCK, \\ Petitioner, \\ $v$. \\ LORIE DAVIS, DIRECTOR, TEXAS \\ DEPARTMENT OF CRIMINAL JUSTICE, \\ CORRECTIONAL INSTITUTIONS DIVISION, \\ Respondents.

\section{ON WRIT OF CERTIORARI TO THE UNITED STATES COURT OF APPEALS FOR THE FIFTH CIRCUIT}

\section{B $\overline{\overline{\text { RIEF FOR THE NATIONAL BLACK LA }}}$ STUDENTS ASSOCIATION AS AMICUS CURIAE IN SUPPORT OF PETITIONER}

Aderson B. Francois

Georgetown University Law Center

Institute for Public

Representation

Civil Rights Clinic

600 New Jersey Avenue Washington, D.C. 20001
Deborah N. Archer Counsel of Record Daniel A. Warshawsky New York Law School Racial Justice Project 185 West Broadway New York, NY 10013 (212) 431-2138

Deborah.Archer@nyls.edu 
TABLE OF CONTENTS

TABLE OF AUTHORITIES ................................... ii

INTEREST OF AMICUS CURIAE ...........................1

SUMMARY OF ARGUMENT..................................

I. There Is DeEPly RoOted IN OUR History, INDELIBLY STAMPED IN OUR PSYCHE, AND

Stubbornly Present In Our Culture a Cruel AND DEHUMANIZING STEREOTYPE THAT BLACK People Are Uniquely Violent AND DANGerous

5

A. The Ideology of Slavery Held as Its Fundamental Tenet that Blacks Were by Their Nature Savage Brutes Prone to Violence and Criminality Unless Domesticated and Made Docile by the Firm Hand of a White Master ...5

B. In the Post Civil War Era, Scientists Maintained that No Greater Menace Faced the Nation than the Threat Posed by the "Load of African Negro Blood"

C. The Progressive Era Exchanged the Biological Determinism of Black Individuals Being Innately Violent with the Cultural Determinism of Black Communities Being Peculiarly Tolerant of Criminality ..................14

D. In the Modern Era, Subtle Skin-Color Coding of Dangerousness Ushered in the Rise of Hoodlums and Villains.... 
$i i$

II. The NarRative OF Black Dangerousness REMAINs Part OF OUR CULTURAL WORLDVIEW .17

A. In a Wide Set of Circumstances Americans Strongly and Automatically Stereotype Blacks as Violent Criminals.

B. The Stereotype of Black Dangerousness Is Constantly Reflected in and Reinforced by Popular Media.

III. This COURT HAS LONG Worked TO FERRET OUT THE Use of RACE IN the CRIMINAL JUstice

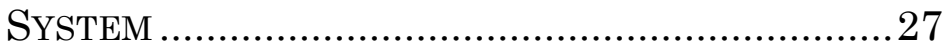

A. Race Can Never Be Allowed to Factor into the Calculus of Guilt or Punishment 27

B. Overt and Subtle Racial Appeals Unjustly Taint Criminal Proceedings

C. This Court Has Routinely Interpreted Procedural Rules and Bars to Permit Review of Impermissible Uses of Race

CONCLUSION 37

\section{TABLE OF AUTHORITIES}

\section{Cases}

Batson v. Kentucky, 476 U.S. 79 (1986) $28,34,35$

Bennet v. Stirling, 2016 WL 1070812 (D.S.C. Mar. 16, 2016). 
Berger v. United States, 295 U.S. 78 (1935)

Bordenkircher v. Hayes, 434 U.S. 357 (1978)

Bryant v. State, 25 S.W.3d 924 (Tex. App. 2000) 31

Carter v. Texas, 177 U.S. 442 (1900)

Cassell v. Texas, 339 U.S. 282 (1950)

Coleman v. Thompson, 501 U.S. 722 (1991) 36

Dawson v. State, 734 P.2d 221 (1987)

Ellis v. Railway Clerks, 466 U.S. 435 (1984)

Ex Parte Virginia, 100 U.S. 339 (1879) 28,34

Ford v. Georgia, 498 U.S. 411 (1991) 34,35

Foster v. Chatman, 578 U. S. 136 S. Ct. 737 (2016) 28,34

Furman v. Georgia, 408 U.S. 238 (1972) 
Hathorn v. Lovorn, 457 U.S. 255 (1982) 35

Kelly v. Stone, 514 F.2d 18 (9th Cir. 1975) 32

Knox v. SEIU, 567 U. S. (2012), 132 S. Ct. 2277 (2012) ......35

Kornegay v. State,

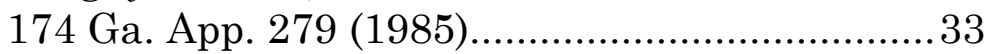

Martin v. Texas, 200 U.S. 316 (1906) 29

Martinez v. Ryan, 566 U. S. _ (2012), 132 S. Ct. 1309 (2012) .....36

McCleskey v. Kemp, 481 U.S. 279 (1987) 28

McFarland v. Smith, 611 F.2d 414 (2d Cir. 1979)

Miller v. North Carolina, 583 F.2d 701 (4th Cir. 1978)................................. 32

Montgomery $v$. Louisiana, 136 S.Ct. 718 (2016) 34

Moore v. Morton, 255 F.3d 95 (3d Cir. 2001)

NFIB v. Sebelius, 567 U. S. (2012), 132 S. Ct. 2566 (2012) ......35 
Norris v. Alabama, 294 U.S. 587 (1935) .............................................28

Oyler v. Boyles, 368 U.S. 448 (1962) .............................................29

Plessy v. Ferguson, 163 U.S. 537 (1896)

Powers v. Ohio, 499 U.S. 400 (1991) 28

Rose v. Mitchell, 443 U.S. 545 (1979) 28,30

State v. Hinton, 43 S.E.2d 360 (1947) 32

Strauder v. West Virginia, 100 U.S. 303 (1879) 28

Swain v. Alabama, 380 U.S. 202 (1965)

Trevino v. Thaler, 133 S. Ct. 1911 (2013) 36

United States ex rel. Haynes v. McKendrick, 481 F.2d 152 (2d Cir. 1973) 32

United States v. Cannon, 88 F.3d 1495 (8th Cir.1996)

United States v. Doe, 903 F.2d 16 (D.C. Cir. 1990) 32 
United States v. Grey, 422 F.2d 1043 (6th Cir. 1970).................................31

United States v. Jones, 159 F.3d 969 (6th Cir. 1998)

United States v. Tuitt, 68 F. Supp. 2 d 4 (D. Mass. 1999).

Wayte v. United States, 470 U.S. 598 (1985) 29

Withers $v$. United States, 602 F.2d 124 (6th Cir. 1979)...................................32

Yick Wo v. Hopkins, 118 U.S. 356 (1886) 29

Statutes

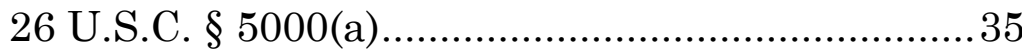

26 U.S.C. § 5000(g)(2) ............................................. 35

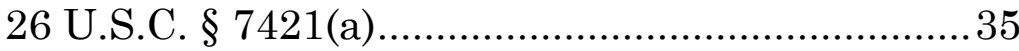

Secondary Sources

ABC News, President Obama and the People Town Hall: A National Conversation, YouTuBe (July 15,

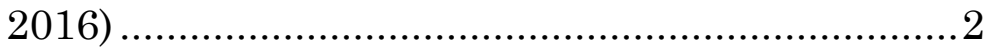

ARthur Zilversmit, The First Emancipation: The ABOLITION OF SlaVERY IN THE NORTH (1967) ......... 7 
B. Keith Payne, Prejudice and Perception: The Role of Automatic and Controlled Processes in Misperceiving a Weapon, 81 J. PERSONALITY \& Soc. PsYcHOL. $181 \quad$ (2001) .................................20

Barbara J. Fields, Ideology and Race in American History, in REGION, RACE, AND RECONSTRUCTION: ESSAYS IN HONOR OF C. VANN WOODWARD (1982).....

BoOKer T. WAShINGTON ET AL., The Negro PROBLEM (1903) ................................................10

Brandon K. Thorp, What Does the Academy Value in a Black Performance, N.Y. TIMES

(Feb. 19, 2016)

Charles Sumner, Vol. 14: His Complete Works (1900) .11

Cindy Boren, Richard Sherman, Frustrated by Reaction, Equates 'Thug' with Racial Slur, WASH. PosT (Jan. 23, 2014) 23

Emily Flitter \& Chris Kahn, Exclusive: Trump Supporters More Likely to View Blacks Negatively, REUTERS (June 28, 2016) 3

Equal Protection and The African American CONSTITUTIONAL EXPERIENCE: A DOCUMENTARY HisTORY (Robert P. Green, Jr. 2000) ....................... 3

Eugene R. Corson, The Future of the Colored Race in the United States from an Ethnic and Medical Standpoint, 15 N.Y. MED. TIMES 193 (1877)....3, 10 
viii

Frances Kellor, EXPERIMENTAL SOCIOLOGY: DESCRIPTIVE AND ANALYTICAL: DELINQUENTS (2010) 15

Frederick A. Bushee, Ethnic Factors in the POPULATION OF BOSTON (1903) ..............................15

Frederick L. HofFman, RACE Traits AND TENDENCIES OF THE AMERICAN NEGRO (1896)........12

George M. Frederickson, The Black Image in the White Mind: The Debate ON AFro-American CharaCter AND DestinY, 1817-1914 (1987) $6,7,8$

Henry M. Boies, Prisoners and Paupers: A Study OF THE ABNORMAL INCREASE OF CRIMINALS AND THE Public Burden of PAUPERISM In the United States; The Causes and the Remedies (1893) ...11

James BALDWin, Notes of A Native Son (1955) ......5

Jason A. Okonofua \& Jennifer L. Eberhardt, Race and the Disciplining of Young Students, $26 \mathrm{~J}$. PSYCHOL. SCI. 617 (2015) .....................................25

Jennifer L. Eberhardt et al., Seeing Black: Race, Crime, and Visual Processing, 87 J. PERSONALITY \& Soc. PSYCHOL. 876 (2004).....................19, 21, 25

John CAmpbell, Negro-Mania: Being an EXAMINATION OF THE FALSELY Assumed EQUALITY OF THE VARIOUs RACES OF MEN (1851) ....................9

Jonathan Capehart, Pictures Put Trayvon Martin on Trial, WASH. Post (May 28, 2013) 
Joshua Correll et al., Event-Related Potentials and the Decision to Shoot: the Role of Threat Perception and Cognitive Control, 42 J. EXP'L PsYCHOL. 120 (2006) 20

Josiah NotT, Two LeCtURES ON THE NATURAL History OF THE CAUCASIAN AND NEgRO RACES (1844) .9

Justin T. Pickett, Reconsidering the Relationship Between Perceived Neighborhood Racial Composition and Whites' Perceptions of Victimization Risk: Do Racial Stereotypes Matter? 50 CRIMINOLOGY 145 (2012)................................25

Kali N. Gross, Colored Amazons: Crime, Violence, and Black WoMEN IN THE City OF BROTHERLY LOVE, 1880-1910 (1st ed. 2006) ........11

Khalil Gibran Muhammad, The Condemnation of BLACKNESS (2011) ..................................13, 14, 15

Kyle Wagner, The Word "Thug" Was Uttered 625 Times on TV on Monday. That's a Lot, DEADSPIN, REGRESSING (Jan. 21, 2014) ................................22

Leon F. Litwack, Trouble IN Mind: Black SOUTHERNERS IN THE AGE OF JIM CROW (1998) ....17

Lincoln Quillian \& Devan Pager, Black Neighbors, Higher Crime? The Role of Racial Stereotypes in Evaluations of Neighborhood Crime 107 AM. J. Soc. 717 (2001).................................................26 
Marli F. Weiner \& Maize Hough, Sex, Sickness AND SLAVERY: IlLNESS IN THE ANTEBELLUM SOUTH (2012)

Phil Mushnick, Classless Serena Celebrated, N.Y. Post (Sept. 16, 2011) ...........................................23

Philip Atiba Goff et al., Not Yet Human: Implicit Knowledge, Historical Dehumanization, and Contemporary Consequences, 94 J. PERSONALITY \& Soc. PsYCHOL. 292 (2008)

Robert J. Sampson \& Stephen B. Raudenbush, Seeing Disorder: Neighborhood Stigma and the Social Construction of 'Broken Windows', 67 Soc. PYSCHOL. Q. 319 (2004)........................................26

ROBERT M. ENTMAN \& ANDREW ROJECKI, THE BLACK Image in the White Mind: Media and Race IN AMERICA (2010) ......................................... 3, 22

Sophie Trawalter et al., Attending to Threat: RaceBased Patterns of Selective Attention, 44 J. ExP'L PSYCHOL. 1322 (2008)............................................19

Tali Mendelberg, RaCe Card: Campaign Strategy, ImPlicit Messages AND the NoRM OF EQUALITY (2001) ............................................6, 23

Ta-Nehisi Coates, Richard Sherman's Best Behavior, The Atlantic (Jan. 20, 2014)..............23

Thomas JefFerson, Notes on the State of VIRGINIA (1832) ..................................................... 
Thomas R. Dew, Professor Dew on Slavery, in THE Pro-SLAVERY ARGUMENT 287 (1853) ........................6

Travis L. Dixon \& Daniel Linz, Overrepresentation and Underrepresentation of African Americans and Latinos as Lawbreakers on Television News, 50 J. CoMM. 131 (2000) .....................................24

W.E.B. Du BoIS, Black RECONSTRUCTION IN AMERICA (1962) ................................................12

W.E.B. Du Bois, The Freedmen's Bureau, Atlantic MONTHLY (Mar. 1901) .............................................10

W.E.B. Du Bois, The Soul of White Folk (1920), reprinted in W.E.B. Du BoIs, W.E.B. Du BoIs: SELECTIONS From His Writings (2014) ................16

William Drayton, The South Vindicated from THE TREASON AND FANATICISM OF THE NorTHERN ABOLITIONISTS (1836) .......................................... 6

William Goodell, The American Slave Code in ThEORY AND PRACTICE (1853) .................................

William L. VAN Deburg, HoOdlums: Black VILLAINS AND SOCIAL BANDITS IN AMERICAN LIFE

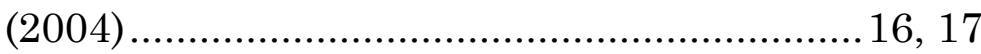




\section{INTEREST OF AMICUS CURIAE ${ }^{1}$}

The National Black Law Students Association ("NBLSA") submits this brief as amicus curiae in support of Petitioner. NBLSA is a membership organization formed in 1968 to promote the educational, professional, political, and social objectives of Black law students. Today, NBLSA is the largest student-run organization in the United States, with nearly 6,000 members, over 200 chapters in our nation's law schools, and six international chapters or affiliates. NBLSA maintains an interest in the development of jurisprudence which guards against racial discrimination and promotes a positive legal framework for addressing matters of civil and constitutional rights. Accordingly, NBLSA has a substantial interest in the outcome of this litigation.

\section{SUMMARY OF ARGUMENT}

On July 14, 2016, President Barack Obama, speaking at a town hall on race relations, acknowledged "what is true for me is true for a lot of African-American men-is there's a greater presumption of dangerousness that arises from the social and cultural perceptions that have been fed to folks for a long time ... And I think it is not as bad as it used to be, but it's still there, and there's a

1 The parties have consented to the filing of this brief. No counsel for a party authored this brief in whole or in part, and no counsel or party made a monetary contribution intended to fund the preparation or submission of this brief. No person other than amicus curiae, its members, or its counsel made a monetary contribution to its preparation or submission. 
history to that."2 In phrasing the notion of Black dangerousness in such personal terms, President Obama undoubtedly did not mean to suggest that most ordinary Americans regard him as dangerous and prone to criminality. The vast majority of Americans no more look upon President Obama as inherently dangerous than they would the Black physician who treats them in the emergency room, the Black firefighter who responds to a call at their home, the Black teacher who speaks with them at a parent-teacher conference, or the Black attorney who appears before them at the bench. But faced with an unfamiliar stranger, placed in stressful circumstances, presented with a criminal defendant, even well-meaning people fall prey to the stereotype that, whether for reason of biology or culture, Black people are inherently violent and dangerous.

This narrative of dangerousness reaches back to slavery when Black people were believed to be not just inferior, but also savage brutes prone to violence and criminality unless domesticated and made docile. Conceived as a popular philosophy, the narrative evolved into a respected scientific doctrine, positing that the very physical attributes of Black people-from the darkness of their skin, to the broadness of their nose, to the coarseness of their hair-were biological manifestations of a lesserevolved human form. When the Civil War ended, conventional wisdom held that freedom made evident in Blacks what slavery had kept hidden by

2 ABC News, President Obama and the People Town Hall: A National Conversation, YouTuBE (July 15, 2016), https://www.youtube.com/watch?v=sNZvIgA0DIc (remarks at 41:58). 
giving "loose reins to the animal."3 During Reconstruction and through Jim Crow, as Black Codes in the South and discriminatory policing in the North literally criminalized Blackness, sociology and statistics replaced Darwinism and eugenics in arguing for innate Black criminality. In the socalled progressive era, well-meaning reformers advocated for more humane treatment of criminals but still warned that the Black criminal was a breed apart because the propensity for crime revealed the faults of an immature race.

The narrative of Black criminality is not some vestigial relic of a long dead past. The most rigorous cognitive and psychological scientific research of the last sixty years has shown that even in our own enlightened modern times, vast segments of society hold the belief that Blacks and Whites occupy different moral universes, that Blacks are more prone to criminality than Whites, and that the most salient aspects of Black character are "laziness, murderous violence, and sexual intemperance." ${ }^{4}$ As recently as June 2016, a Reuters/Ipsos public opinion poll revealed that a shockingly high number of people of all political stripes described Blacks as unintelligent, lazy, violent, and criminal. ${ }^{5}$

3 Eugene R. Corson, The Future of the Colored Race in the United States from an Ethnic and Medical Standpoint, 15 N.Y. Med. Times 193, 201 (1877); Equal Protection and The AFRICAN AMERICAN CONSTITUTIONAL EXPERIENCE: A DOCUMENTARY HISTORY 149-50 (Robert P. Green, Jr. 2000).

${ }^{4}$ RoberT M. ENTMAN \& ANDREW ROJECKI, THE BLACK IMAGE IN THE WHITE Mind: MEDIA AND RACE IN AMERICA 41 (2010).

5 Emily Flitter \& Chris Kahn, Exclusive: Trump Supporters More Likely to View Blacks Negatively, REUTERS (June 28, 2016, 8:41 PM), http://www.reuters.com/article/us-usa-electionrace-idUSKCNOZE2SW. 
So, when an expert witness told the jury that Mr. Buck was dangerous because he is Black, he dredged up into the open for all members of the jury to see the monstrous specter that is never far from the surface: the violent Black brute, the single most fearful, dehumanizing, and cruel stereotype Black people have had to endure. In so doing, he did not just make a passing reference to race; he made race the central question for determining whether Mr. Buck should be put to death. This is constitutionally and morally indefensible.

Any procedure that bars review of a death sentence must give way to the greater constitutional and moral imperative of ferreting out impermissible appeals to a defendant's race. Historically, Black defendants have been subjected to greater rates of charging, higher rates of conviction, and longer and harsher sentences. This Court has worked deliberately to correct these disparities, to exorcise race from our criminal justice system, and to develop a jurisprudence that fosters justice and equity. Therefore, this Court should not now let stand a procedural bar to consideration of a defendant's claim that race was a factor in a jury's death sentence.

\section{ARGUMENT}




\section{There Is Deeply Rooted IN OuR History, INDELIBLY STAMPED IN OUR PSYCHE, AND Stubbornly Present In Our Culture a Cruel and Dehumanizing Stereotype that Black People Are Uniquely Violent and DANGEROUS}

\section{A. $\square$ The Ideology of Slavery Held as Its Fundamental Tenet that Blacks Were by Their Nature Savage Brutes Prone to Violence and Criminality Unless Domesticated and Made Docile by the Firm Hand of a White Master}

Thomas Jefferson believed that "the blacks, whether originally a distinct race, or made distinct by time and circumstances, are inferior to the whites in the endowments both of body and mind." 6 Though he conceded he did not have much evidence to back up his opinion, he still insisted that "in general their existence appears to participate more of sensation than reflection."7 In Jefferson's time the racial prejudice that would eventually lead White Americans to conclude that "black men were not really men but cattle," 8 had not yet quite hardened into an ideology of race that posited that Black people were biologically a lower life form. However, in both North and South, among both slaveholders and abolitionists, the belief that Black people were an alien and dangerous presence gained wide currency in early Nineteenth century America.

6 Thomas Jefferson, Notes on the State of Virginia 150 (1832).

${ }^{7}$ Id. at 146.

8 JAMEs BALDWIn, Notes OF A NATIVE SON 168 (1955). 
After Virginia briefly considered but ultimately rejected legislative proposals that would have led to emancipation, Professor Thomas R. Dew of William and Mary College explained that Black people were unfit for emancipation because they were "differing from us in color and habits and vastly inferior in the scale of civilization." 9 Like Jefferson, Dew concluded that the supposed indolent and violent nature of Black people resulted from "an inherent and intrinsic cause." 10 Defending slavery from abolitionist argument, William Drayton, a Charleston lawyer, argued that "personal observation must convince every candid man that the negro is constitutionally indolent, voluptuous, and prone to vice, that his mind is heavy, dull, and unambitious, that the doom that has made the African in all ages and countries, a slave-is the natural consequence of the inferiority of his character."11

Even Northern abolitionists were not altogether free of the idea of Black criminality. A group of New Jersey abolitionists cautioned that free Blacks "were given to idleness, frolicking, drunkenness, and in some few cases dishonesty." 12 A Philadelphia abolitionist "described most

\footnotetext{
9 George M. Frederickson, The Black Image in the White Mind: The DEBATE ON AFro-AMERICAN CHARACTER AND DESTINY, 1817-1914 45 (1987)

10 Thomas R. Dew, Professor Dew on Slavery, in The ProSLAVERY ARGUMENT 287, 429 (1853).

11 William DRAYTON, THE SOUTH VINDiCATED FROM THE TREASON AND FANATICISM OF THE NORTHERN ABOLITIONISTS 232 (1836).

12 Tali Mendelberg, Race Card: Campaign Strategy, IMPLICIT MESSAGES AND THE NORM OF EQUALITY 32 (2001).
} 
Philadelphia negroes as degraded and vicious."13 A New York abolitionist society bemoaned "the looseness of manners and depravity of conduct in many of the persons of Colour in this city." 14 Alarmed by what it perceived as the "depravity of the negro," and concerned about Blacks becoming "both injurious and burdensome," the Massachusetts legislature appointed a committee to study restricting Black immigration to the state. ${ }^{15}$

The doctrine of inherent Black inferiority first began as a popular emotional justification for slavery. However, it soon became "the basis of a world view, an explicit ideology around which the beneficiaries of white supremacy could organize themselves and their thoughts." 16 Central to this worldview was the notion that Black people were not just inferior, but also and more importantly that they were by their very nature savage brutes prone to violence and criminality unless "domesticated" and made docile in slavery. Thus, in order to reconcile the notion of Blacks as "naturally mendacious ...and thievish" 17 with the Southern claim of slaves as "contented, peaceful and harmless,"18 proslavery propagandists conjured up the concept of the duality of negro character:

According to this theory, the Negro was by nature a savage brute. Under

\footnotetext{
${ }^{13}$ FREDERICKSON, supra note 9, at 4.

14 ARTHur Zilversmit, The First Emancipation: The ABOLITION OF SLAVERY IN THE NORTH 223-24 (1967).

$15 \mathrm{Id}$. at 225.

16 FrEDERICKSON, supra note 9, at 47.

17 William Goodell, The American Slave Code in Theory AND PRACTICE 17 (1853).

18 FREDERICKSON, supra note 9 , at 52 .
} 
slavery, however, he was domesticated or, to a limited degree, civilized. Hence docility was not so much his natural character as an artificial creation of slavery. As long as the control of the master was firm and assured, the slave would be happy, loyal and affectionate; but remove or weaken the authority of the master, and he would revert to type as bloodthirsty savage. ${ }^{19}$

In the decades preceding the Civil War, the popular philosophy of the dual Black character evolved into a respected scientific doctrine. In 1839, Dr. Samuel George Morton published, CRANIA AMERICANA, or what he called an empirical study of racial differences. According to Morton, careful examination of the size and shapes of different types of men led to the inevitable conclusion that Blacks represented an altogether different species. ${ }^{20}$ Dr. Josiah Nott, an ethnologist originally from Mobile, Alabama who would later become the Dean of the School of Science at Harvard University, firmly believed that Africa was the homeland of "a succession of human beings with intellects as dark as their skins," 21 and "attempted to convince educated Americans that the Negro was not a blood brother to the whites." 22 Relying in part on measurements of skull capacities, facial features, and even hair textures of Black and White cadavers, Nott concluded that the anatomical differences

\footnotetext{
${ }^{19} \mathrm{Id}$. at $53-54$.

${ }^{20} \mathrm{Id}$. at $74-75$.

21 Marli F. Weiner \& Maize Hough, Sex, Sickness AND SLAVERY: ILLNESS IN THE ANTEBELLUM SOUTH 18 (2012).

${ }^{22}$ FREDERICKSON, supra note 9 , at 75 .
} 
between Whites and Blacks were "greater than the differences in the skeleton of the Wolf, Dog and Hyena, which are allowed to be distinct species." ${ }^{23}$

Though Nott was indisputably a White racialist committed to the cause of slavery, his views of Black savagery were made respectable by a veneer of scientific discourse. Thus, in 1851, John Campbell, a prominent scholar, was able to use Nott's work to publish a remarkable volume titled Negro-Mania, in which he summarized the scientific consensus on Black savagery:

We every where find proofs of . . . inflexible cruelty, selfishness and disposition to cheat, a want of all sympathetic impulses and feelings, the most brutal apathy and indolence, unless roused by the pressure of physical want, or stimulated by the desire of revenge and the thirst of blood. ${ }^{24}$

B. In the Post Civil War Era, Scientists Maintained that No Greater Menace Faced the Nation than the Threat Posed by the "Load of African Negro Blood"

The Civil War brought former slaves "suddenly, violently ...in a new birthright, at a time

23 Josiah NotT, Two LeCtUREs ON THE NATURAL History OF THE CAUCASIAN AND NEGRO RACES 25 (1844).

24 John CAmpbell, Negro-Mania: Being an Examination of

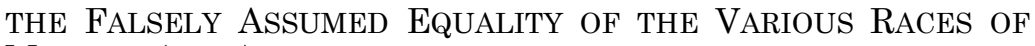
MEN 137 (1851). 
of war and passion, in the midst of the stricken, embittered population of their former masters." 25 Post-bellum scientists took stock of these new birthright citizens and concluded that "during slavery ... . so far as the merely physical man was concerned they were better off . . . But since the war and emancipation things have reversed; freedom gave loose reins to the animal." 26 Chief among scientists warning about Black criminality was Nott. In an influential article titled "The Negro Problem," he explained that Blacks were "bred first in a savagery that had never been broken by the least efforts towards a higher state." 27 He insisted that "judged by the light of all experience, these people are a danger to America greater and more insuperable than any of those that menace the other great civilized states of the world," and that no challenge facing the country was as great as "compared to this load of African negro blood that an evil past has imposed upon us." 28

While Nott harbored no doubt about the inherent criminality of Black people, he cautioned that more research was needed to fully understand its origins. The American ethnographers, anthropologists, physicians, penologists and statisticians who took up the call for more research almost uniformly concluded, as did Henry Martin Boies, a leading penologist, that Blacks were prone

\footnotetext{
25 W.E.B. Du Bois, The Freedmen's Bureau, AtLantic MonThly (Mar. 1901) at 357, http://www.theatlantic.com/past/docs/issues/01mar/dubois.htm. ${ }^{26}$ Corson, supra note 3, at 196.

27 Booker T. Washington et AL., The Negro Problem 697 (1903).

${ }^{28} \mathrm{Id}$. at 699.
} 
to criminality because they had "strong animalism by nature and cultivation," which resulted in a lack of "virtue and little moral restraint." 29

Greatly influenced by social Darwinism, eugenics and other European theories of hereditary criminality, post-bellum social scientists "largely understood criminals as falling into one of two categories: occasional and habitual. Most crime stemmed from poverty, poor environment, and poor moral training, typical motivating factors for occasional criminality. Habitual criminals, however, were biologically deficient and morally bankrupt individuals." 30 To these scientists, "habitual criminals possessed common atavistic traitsphysical and mental characteristics that otherwise distinguished them from normal human beings." Superimposed upon what Charles Sumner called the "oligarchy of the skin," 31 eugenist theories of criminality as being hereditary effectively equated Black skin with criminal traits. As such, Americans "envisioned civilized White heterosexual society in a perilous battle not simply to maintain social, political, and moral authority, but also to preserve their gene pool and the sanctity of whiteness." 32

Of course, the tragic irony is that many of these scientists and reformers warning of the

${ }^{29}$ Henry M. Boies, Prisoners And Paupers: A Study of the ABNORMAL INCREASE OF CRIMINALS AND THE PUBLIC BURDEN OF PAUPERIsM IN THE United States; the CAUses AND THE REMEDIES 73 (1893).

30 Kali N. Gross, Colored Amazons: Crime, Violence, AND BlaCK WOMEN IN THE CITY OF BROTHERLY LOVE, 1880-1910 133 (1st ed. 2006).

${ }^{31}$ Charles Sumner, Vol. 14: His COMPLETE Works 292 (1900).

32 GROss, supra note 30, at 133. 
dangers of Black criminality in the post-bellum era were able to offer what seemed to be irrefutable data of a wave of Black crime at the end of the Civil War. That is because the Black Codes enacted by every single Southern state had succeeded in essentially criminalizing Blackness. ${ }^{33}$ To social scientists studying crime in America, the innate criminal nature of Black people rather than Southern Black Codes and Northern racial discrimination served to explain the seeming prevalence of crime in the Black population. In fact, the notion of Blacks as inherently criminal gained wide purchase in the post-bellum years in part because most of the scientists advancing that theory claimed to be dispassionate truth seekers free of irrational racial prejudice.

Thus, in 1896, the same year this Court validated American racial apartheid in Plessy $v$. Ferguson, 163 U.S. 537 (1896), Frederick Ludwig Hoffman, a German-born and educated actuary and statistician from Prudential Insurance Company, published a study warning that freedom had made evident an aspect of the Black character that slavery had managed to keep hidden: a propensity for criminality. ${ }^{34}$ Specifically, Hoffman observed that in slavery it was "well known that neither crime [nor] pauperism existed." 35 But, using data from the 1890 census, Hoffman showed that, while Blacks were

33 See W.E.B. Du Bois, Black ReCONSTRUCTION IN AMERICA 167 (1962) (noting that although "[n] egroes were no longer real estate... [n]egroes were liable to a slave trade under the guise of vagrancy and apprenticeships laws").

34 See generally Frederick L. HOFFMAN, RACE TRAITS AND TENDENCIES OF THE AMERICAN NEGRO (1896).

${ }^{35} \mathrm{Id}$. at 217. 
only 12 percent of the population, they represented 30 percent of all prisoners, 30 percent of those imprisoned for violent crimes, 41 percent of those imprisoned for rape, and nearly 50 percent of those imprisoned for arson. ${ }^{36}$ While the numbers appeared, as Hoffman put it, to speak for themselves, in truth Hoffman's statistics were part of a carefully crafted racial narrative all the more pernicious for seemingly being scientifically neutral. Hoffman's own data showed crime statistics for Blacks were no different than those of immigrants and poor Whites. But, whereas Hoffman explained crime among poor White immigrants as a function of economic deprivation and societal discrimination, he insisted that crime among Black people was a function of innate characteristics. Hoffman's use of data was revolutionary because he "combined crime statistics with a well-crafted white supremacist narrative to shape the reading of black criminality while trying to minimize the appearance of doing so." 37 Indeed, by carefully reporting not just crime statics but also data showing increase in education among Blacks, Hoffman was able to argue that beneficial social institutions such as schools and churches that would normally have civilizing effects on White criminals had no impact on Blacks. His words bear reproducing in full:

I have given the statistics of the general progress of the race in religion and education for the country at large, and have shown that in church and school

36 Khalil Gibran Muhammad, The Condemnation of BLACKNESS 51 (2011).

${ }^{37} \mathrm{Id}$. 
the number of attending members or pupils is constantly increasing; but in statistics of crime and the data of illegitimacy the proof is furnished that neither religion nor education has influenced to an appreciable degree the moral progress of the race. Whatever benefit the individual colored man may have gained from the extension of religious worship and educational processes, the race as a whole has gone backwards rather than forwards. ${ }^{38}$

\section{C. $\square$ The Progressive Era Exchanged the Biological Determinism of Black Individuals Being Innately Violent with the Cultural Determinism of Black Communities Being Peculiarly Tolerant of Criminality}

At the turn of the twentieth century, social scientists and reformers abandoned theories of biological determinism equating Blackness with crime. However, in search of an explanation for what they perceived as a disproportionate share of criminal behavior by Black people, arguably wellmeaning reformers and supposedly enlightened scientists exchanged one form of racial determinism for another: crime was unique to Blacks not by reason of their biology but by reason of their culture. That is to say, reformers explained White criminal behavior as a function of general socio-economic forces, but described Black criminal behavior as a function of particular Black culture.

${ }^{38} I d$. at 52. 
15

For example, Frances Kellor, a White female criminologist, traveled the South measuring body sizes and shapes of Black female prisoners to show that there were no inherent biological differences between Black and White criminals. ${ }^{39}$ However, looking at crime statistics, Kellor nonetheless drew an essentialist distinction between White and Black criminals: "The Negroes' criminality is that of an undeveloped race...The Negroes' crime show an absence of social and personal responsibility, and are an outgrowth of impulse rather than of well-laid plans and complicated schemings." 40 Frederic Bushee, a leading Boston reformer and author of immigrant life, noted the high crime rate in Irish and Italian communities. He also remarked that they brought "many valuable traits to the American people," and that "it is fortunate that they possess the characteristics which make them easily assimilable." 41 However, whereas rampant crime in immigrant communities did not prevent reformers like Bushee from understanding the nurturing of immigrants as key to the nation's health, they remained adamant that culturally, Blacks were different: "The Negroes in general reveals the faults of an immature race" and that, unlike immigrants, assimilation into American society was "not desirable." 42

As always, W.E.B. Du Bois put it best:

${ }^{39} \mathrm{Id}$. at 88.

40 Frances Kellor, Experimental Sociology: Descriptive AND ANALYTICAL: DELINQUENTS 31 (2010).

41 Frederick A. Bushee, Ethnic FaCtors in the Population OF BosTON 158 (1903).

${ }^{42} \mathrm{Id}$. at $115,160$. 
Murder may swagger, theft may rule and prostitution flourish, and the nation gives but a spasmodic, intermittent and lukewarm attention. But let the murderer be black or the thief brown or the violator of womanhood have but a drop of Negro blood, and the righteousness of the indignation sweeps the world. Nor would this fact make the indignation less justifiable did not we all know that it was blackness that was condemned, and not the crime. ${ }^{43}$

\section{In the Modern Era, Subtle Skin-Color Coding of Dangerousness Ushered in the Rise of Hoodlums and Villains}

Between the two world wars and up until the modern civil rights movement, the naked racial theories that painted Blacks as black-hearted villains did not altogether disappear from mainstream consciousness. Indeed, as the centuries progressed, the various malignancies associated with Blackness were conflated into a fearful specter of death and destruction. The "bad classes of Negroes" seemed to grow larger each year; their criminal appetites and deviant sexual desires less easily sated than ever before." 44 In those years, the narrative of Black violence acquired explicit sexual overtones, in

\footnotetext{
${ }^{43}$ W.E.B. Du BoIs, The Soul of White FolK (1920), reprinted in W.E.B. Du BoIs, W.E.B. Du BoIs: SELECTIONS From His WRITINGS 167 (2014).

44 William L.Van Deburg, Hoodlums: Black Villains and SOCIAL BANDITS IN AMERICAN LIFE 149 (2004).
} 
which "two-legged monsters," consumed by lust and "rotten" with venereal diseases posed a constant threat to White women. ${ }^{45}$

However, with the advent of the civil rights movement, overt expressions of Black people as racial villains fell out of fashion, to be replaced with more coded but no less potent language. To be sure, some still clung to overt biological claims. Thus, in reaction to civil disorder and unrest growing out of civil rights protests, William Parker, then the Chief of Police for Los Angeles, explained "you cannot ignore the genes in the behavior pattern of people," comparing Black "hoodlums" to monkeys in a zoo. ${ }^{46}$ But for the most part, descriptions of Black criminality became more coded and subtle. Individuals, who after years of discrimination, finally reacted out of frustration, were typically described as "lacking respect for authority," "hoodlums," "marauders," or engaged in "guerilla warfare." 47

\section{The Narrative of Black Dangerousness REMAINS PART OF OUR CUlTuRAL WORLDVIEW}

Historian Barbara Fields tells us that "ideas about color, like ideas about anything else derive their importance, indeed their very definition, from their context." 48 The automatic presumption of Black

\footnotetext{
${ }^{45}$ LeOn F. LiTwack, Trouble In Mind: Black Southerners IN THE AGE OF JIM CROW 301 (1998).

46 VAN DEBURG, supra note 44, at 41.

${ }^{47} \mathrm{Id}$. at $152-53$.

${ }^{48}$ Barbara J. Fields, Ideology and Race in American History, in REGION, RACE, AND RECONSTRUCTION: ESSAYS IN HONOR OF C. VANN WOODWARD 143, 146 (1982).
} 
dangerousness is not driven by any sort of primordial biological impulse, but is a social construct that has been, in President Obama's words, "fed to folks for a long time." And, the most rigorous social science of the last sixty years shows that this social construct, ancient as it may be, remains part of our cultural worldview.

\section{A. In a Wide Set of Circumstances Americans Strongly and Automatically Stereotype Blacks as Violent Criminals}

Social scientists have long confirmed what most of us instinctively know: we all carry implicit biases against others who we perceive to be different from us. In the case of Blacks:

The stereotype of Black Americans as violent and criminal has been documented by social psychologists for almost 60 years. Researchers have highlighted the robustness and frequency of this stereotypic association by demonstrating its effects on numerous outcome variables, including people's memory of who was holding a deadly razor in a subway scene, people's evaluation of ambiguously aggressive behavior, people's decisions to categorize weapons as weapons, the speed at which people decide to shoot someone holding a weapon, and the probability that they will shoot at all. Not only is the association between 
Blacks and crime strong, it also appears to be automatic." 49

The Implicit Aptitude Test ("IAT") is the most rigorous study on implicit racial bias and tests automatic associations by individuals. The most widely known IAT pairs faces of Black or White men with "good" or "bad" words. Without fail, the test shows that the majority of takers are slower to associate Black faces with "good" words. The most notable and extreme unconscious biases that social scientists have discovered are enduring stereotypes of Black people as dangerous, less-than-human criminals. Even when people are supposedly unaware of historical stereotypes associated with Black people, they associate Blacks with qualities that fit these historical biases. Thus, an IAT using Black and White faces and pictures of apes and nonape animals showed that individuals associate Black people with apes even though the majority of participants indicated that they had never heard of the Blacks as apes stereotype. ${ }^{50}$

But social science research has gone beyond just unconscious associations. Cognitive scientists and psychologists have used selective-attention studies to demonstrate that people feel more threatened by Black people than White people. ${ }^{51}$ The

49 Jennifer L. Eberhardt et al., Seeing Black: Race, Crime, and Visual Processing, 87 J. PERSONALITY \& SOC. PsYCHOL. 876, 876 (2004).

${ }^{50}$ Philip Atiba Goff et al., Not Yet Human: Implicit Knowledge, Historical Dehumanization, and Contemporary Consequences, 94 J. PERSONALITY \& Soc. PSYCHOL. 292, 292-306 (2008).

51 Sophie Trawalter et al., Attending to Threat: Race-Based Patterns of Selective Attention, 44 J. EXP'L PSYCHOL. 1322, 1322-27 (2008). 
theory of selective attention is that people pay more attention to things that are perceived as threatening. It originally applied to proven threats like spiders and snakes, but studies have discovered that Black men are also viewed as threats. For example, in one study participants found a dot on a screen more quickly if it appeared where there had previously been a Black face than if it appeared where there had been a White face, demonstrating selective attention. ${ }^{52}$ Another study found that people were more likely to misperceive an object as a weapon when held by a Black person than when held by a White person and are also more likely to shoot an unarmed Black person than an unarmed White person. ${ }^{53}$ When people are primed with a Black face-meaning it flashes in front of them and they do not even realize they have seen it-they are faster to identify a gun and more likely to mischaracterize a tool as a weapon, whereas when people are primed with a White face, they are faster to identify a tool. ${ }^{54}$

In 2004, scientists from Yale University, Stanford University, the Pennsylvania State University, and the University of California, Los Angeles collaborated on a groundbreaking paper, Seeing Black: Race, Crime, and Visual Processing. The paper's findings are striking: "When officers were given no information other than a face and when they were explicitly directed to make

${ }^{52} \mathrm{Id}$.

53 Joshua Correll et al., Event-Related Potentials and the Decision to Shoot: the Role of Threat Perception and Cognitive Control, 42 J. EXP'L PSYCHOL. 120, 120-28 (2006).

54 B. Keith Payne, Prejudice and Perception: The Role of Automatic and Controlled Processes in Misperceiving a Weapon, 81 J. PERSONALITY \& SOC. PSYCHOL. 181, 181-92 (2001). 
judgments of criminality, race played a significant role in how those judgments were made. Black faces looked more criminal to police officers; the more Black, the more criminal." 55 Their findings also showed that stereotyping Blacks as inherently dangerous has a perverse looping effect, in which Blackness not only triggers association with criminality but also magnifies it; when shown a Black face, people who associate Blackness with criminality misremember the Black face as even more stereotypically Black.

In eerily prescient language, the scientists concluded that one inescapable implication of their findings is that:

Police officers may face elevated levels of danger in the presence of White armed suspects in comparison with Black armed suspects. For example, if police officers have a delayed response to White suspects with guns or knives these officers may be more likely to get hurt, shot, or killed when confronting White armed suspects in comparison with Black suspects. In contrast, unarmed, innocent Blacks may easily become targets of intense visual surveillance by both police officers and the lay public. With their eyes, perceivers may tie individual Black targets to a group-based suspicion-and sadly, Black people who appear stereotypically Black may be the most likely of all to feel the tug. ${ }^{.6}$

55 Eberhardt et al., supra note 49, at 181-92.

${ }^{56} \mathrm{Id}$. 


\title{
B. The Stereotype of Black Dangerousness Is Constantly Reflected in and Reinforced by Popular Media
}

\begin{abstract}
Nowhere is the stereotype of Black dangerousness more prevalent than in modern popular media. Today, the most common negative stereotypes of Black people are "impressions of laziness, murderous violence, and sexual intemperance." 57 In that way, all manners of national debates about race-from parenting to education to housing-are driven by and even resolved with this idea of the excessive criminality of Black people.
\end{abstract}

When Richard Sherman, a Black professional football player, gave an interview in which he asserted that he was the best at his position, he sparked extensive attention from news programs and on social media. Sherman, who graduated with a 3.9 GPA from Stanford University, was called "classless," a "monkey," a "thug," and "ghetto," among other racial epithets on social media. Indeed, the word "thug" was used 629 times the day after the interview. ${ }^{58}$ Author Ta-Nehisi Coates opined that onlookers, incapable of seeing Sherman as an

${ }^{57}$ Entman \& Rojecki, supra note 4, at 41.

58 Kyle Wagner, The Word "Thug" Was Uttered 625 Times on TV on Monday. That's a Lot, DEADSPIN, REGRESSING (Jan. 21, 2014), http://regressing.deadspin.com/the-word-thug-wasuttered-625-times-on-tv-yesterday-1506098319. 
individual, "instead [saw] the sum of all American fears—monkey, thug, terrorist, nigger."59

Political scientist Tali Mendelberg explains that in the post-civil rights era, explicit race-based appeals that violate norms of equality have been replaced by more subtle visual imagery and coded language that tap into persistent racial prejudices and fears. 60 The racially charged word "thug" functions much in this manner. A contemporary incarnation of the "Black brute" and "Negro savage" archetypes, it connotes violence and brutishness. In 2011, for example, the New York Post compared tennis player Serena Williams to a "street thug," after she yelled at a chair umpire during the U.S. Open. ${ }^{61}$ Michelle Bachman, Rush Limbaugh, Karl Rove, and many others frequently label President Obama "thuggish" and a "Chicago thug."62

The word has been used, too, in the media coverage around the recent shooting deaths of young Black men. For instance, when George Zimmerman's defense team released photographs of 17-year-old Trayvon Martin showing off gold teeth, the Washington Post noted how the tactic fed

59 Ta-Nehisi Coates, Richard Sherman's Best Behavior, THE ATLANTIC (Jan. 20, 2014), http://www.theatlantic.com/entertainment/archive/2014/01/rich ard-shermans-best-behavior/283198/

60 MendelBeRG, supra note 12 , at 6 .

${ }^{61}$ Phil Mushnick, Classless Serena Celebrated, N.Y. PosT (Sept. 16, 2011), http://nypost.com/2011/09/16/classless-serenacelebrated/.

62 Cindy Boren, Richard Sherman, Frustrated by Reaction, Equates 'Thug' with Racial Slur, WASH. POST (Jan. 23, 2014), https://www.washingtonpost.com/news/early-

lead/wp/2014/01/23/richard-sherman-frustrated-by-reactionequates-thug-with-racial-slur/. 
directly into the narrative "painting Trayvon Martin as a thug who deserved to die."63

The narrative that Blacks are inherently criminal is emphasized further by the overrepresentation of Blacks in crime reporting. ${ }^{64}$ One study, which tracked the 2014 news coverage of every major New York network affiliate, found that while 51 percent of the people arrested by the NYPD for violent crime are Black, in evening news coverage Blacks were represented as the suspects 75 percent of the time. This narrative also controls what kinds of stories are told about Black people and Black culture. The New York Times recently analyzed the roles that have earned Black actors Academy Awards nominations, revealing how violence and criminalization figure prominently in depictions of Black life. Since the first awards show in 1929, Black men have been nominated twenty times. Thirteen of those performances involved being arrested or incarcerated and fifteen involved violent or criminal behavior. ${ }^{65}$

The effect of this relentless narrative is significant. A national survey conducted in 2010

\footnotetext{
63 Jonathan Capehart, Pictures Put Trayvon Martin on Trial, WASH. POST (May 28, 2013). , https://www.washingtonpost.com/blogs/postpartisan/wp/2013/05/28/pictures-put-trayvon-martin-on-trial/ 64 Travis L. Dixon \& Daniel Linz, Overrepresentation and Underrepresentation of African Americans and Latinos as Lawbreakers on Television News, 50 J. CoMM. 131, 131-54 (2000).

65 Brandon K. Thorp, What Does the Academy Value in a Black Performance, N.Y. TIMES (Feb. 19, 2016), http://www.nytimes.com/2016/ 02/21/movies/what-does-theacademy-value-in-a-black-performance.html.
} 
asked White respondents to estimate the percentage of burglaries, illegal drug sales, and juvenile crime committed by Blacks. The researchers found that the respondents overestimated actual Black participation in these crimes-measured by arrests-by approximately 20 to 30 percent. ${ }^{66}$

When a narrative is so widely circulated, it comes to bear on every aspect of life. For instance, a 2015 study found that starting at age ten, Blacks were viewed as less innocent than other children. Researchers showed a group of female K-12 teachers identical school records of a fictitious middle school student who had misbehaved. Some teachers received the records labeled with a stereotypically Black name, while others reviewed records labeled with a stereotypically White name. When asked how they would respond to the infractions, teachers were more likely to escalate the response when the student was believed to be Black. The study also found that when a student was believed to be Black, teachers were more likely to attribute the behavior to a larger pattern, rate the incidents as more troubling and warranting of discipline, and were more likely to predict future suspensions. ${ }^{67}$

Research also shows that the presence of Blacks in a neighborhood correlates to the level of perceived crime in that neighborhood. A 2001 study

\footnotetext{
66 Justin T. Pickett, Reconsidering the Relationship Between Perceived Neighborhood Racial Composition and Whites' Perceptions of Victimization Risk: Do Racial Stereotypes Matter?, 50 CRIMINOLOGY 145, 155-56, 160 (2012).

67 Jason A. Okonofua \& Jennifer L. Eberhardt, Race and the Disciplining of Young Students, 26 J. PsYCHOL. SCI. 617 (2015).
} 
of residential surveys and police data from Seattle, Chicago, and Baltimore found a positive association between how residents perceived the level of crime in their neighborhood and the percentage of young Black men living in that neighborhood, even when controlling for a variety of neighborhood characteristics. 68 A 2004 study by researchers from Harvard and the University of Michigan found that as the concentration of minority groups in a neighborhood increases, residents of all races perceive more "disorder," even after accounting for personal characteristics of the respondents and neighborhood conditions. ${ }^{69}$

The idea of Black criminality has become so ingrained in the national consciousness that it is encapsulated in a single racially coded phrase: Black-on-Black crime. This absurd phrase, which is rarely explained but often repeated even by supposedly well-meaning people, is meant to somehow convey the idea that Blacks are so violent that they even kill "their own kind." The truth is Black intra-racial crime is neither unique nor unnatural. The vast majority of violent crimes are intra rather than interracial, and this is particularly true in a society that remains as racially segregated as ours. Yet, the fact that in ordinary discourse the idea of White on White crime never seems to register as a real phenomenon perhaps only goes to show

${ }^{68}$ Lincoln Quillian \& Devan Pager, Black Neighbors, Higher Crime? The Role of Racial Stereotypes in Evaluations of Neighborhood Crime 107 AM. J. Soc. 717, 717-67 (2001).

69 Robert J. Sampson \& Stephen B. Raudenbush, Seeing Disorder: Neighborhood Stigma and the Social Construction of 'Broken Windows', 67 Soc. PyschOL. Q. 319, 319-42 (2004). 
how we have so thoroughly made Blacks villains and villains Black.

\section{ThIS COURT HAS LONG WORKED TO FERRET OUT THE USE OF RACE IN THE CRIMINAL JUSTICE SYSTEM}

In light of the history and nature of stereotype catalogued above, the injection of Mr. Buck's race into his sentencing proceeding is extraordinary because for so long this Court has endeavored to remove race from the calculus of guilt and punishment. Jurisprudential development in criminal procedure reflects this Court's profound understanding that racism infects our institutions and must be stamped out wherever possible.

\section{A. $\square$ Race Can Never Be Allowed to Factor into the Calculus of Guilt or Punishment}

Perhaps the central purpose of our criminal law is the regulation of undesirable behavior. By defining behavior that is undesirable, and by prescribing appropriate punishment for that behavior, criminal law not only achieves retribution but also deters defendants and others from engaging in such behavior in the future. The process of criminal law, then, involves determining whether a defendant engaged in proscribed conduct and affording appropriate punishment. A person's race is irrelevant in both matters; allowing race to be considered either in determining guilt or in proscribing punishment is arbitrary and pernicious. Indeed, allowing race to infect criminal law undermines the credibility and integrity of the 
criminal justice system. But more than that, allowing race to influence a finding of guilt or a determination of punishment is morally repugnant.

This Court has long endeavored to protect the integrity and fairness of our legal system against the effects of the arbitrary consideration of race, commanding that courts engage in "unceasing efforts to eradicate racial prejudice from our criminal justice system" McCleskey v. Kemp, 481 U.S. 279, 310 (1987) (internal citation omitted), because "[d]iscrimination on the basis of race, odious in all aspects, is especially pernicious in the administration of justice," Rose v. Mitchell, 443 U.S. 545, 555 (1979). For example, this Court has repeatedly insisted that exclusion of an otherwise qualified person from serving on a jury on account of race violates due process. See Ex Parte Virginia, 100 U.S. 339, 345 (1879) ("The Fourteenth Amendment secures . . . an impartial jury . . . selected or chosen without discrimination against such jurors because of their color"); Strauder v. West Virginia, 100 U.S. 303, 309-10 (1879) ("That colored people are singled out and expressly denied by a statute all right to participate...as jurors...is practically a brand upon them, affixed by the law, an assertion of their inferiority, and a stimulant to that race prejudice which is an impediment to securing to individuals of the race...equal justice."). See also Foster $v$. Chatman, 578 U. S. _ , 136 S. Ct. 737 (2016) ("The Constitution forbids striking even a single prospective juror for a discriminatory purpose"); Powers v. Ohio, 499 U.S. 400, 411 (1991); Batson v. Kentucky, 476 U.S. 79, 85 (1986); Cassell v. Texas, 339 U.S. 282, 287 (1950); Norris v. Alabama, 294 
U.S. 587 (1935); Martin v. Texas, 200 U.S. 316, 319 (1906); Carter v. Texas, 177 U.S. 442, 447 (1900).

Similarly, this Court has held that selective prosecution on the basis of race violates due process. See Wayte v. United States, 470 U.S. 598, 608 (1985); Bordenkircher v. Hayes, 434 U.S. 357, 364 (1978); Oyler v. Boyles, 368 U.S. 448, 456 (1962); Yick Wo v. Hopkins, 118 U.S. 356, 374 (1886). Notwithstanding this Court's commitment to ferreting out selective prosecution on the basis of race, this practice continues to infect our criminal justice system, and lower federal and state courts continue to confront it. In one illustrative case, a Black defendant challenged his prosecution on the ground it was racially motivated. United States $v$. Jones, 159 F.3d 969 (6th Cir. 1998). The defendant pointed to the fact that police officers made custom t-shirts celebrating his arrest and that of his wife, who was also Black, while deliberately leaving out a White codefendant, and then sent a postcard of a Black woman with bananas on her head to the defendant in jail. $I d$. at 975 . The Sixth Circuit found that the "undeniably shameful" conduct of the officers "was not only outrageous and unprofessional, but also racially motivated." Id. at 977 .

Analogously, prosecution for crack cocaine possession or sale has played out along racial lines. See, e.g., United States v. Tuitt, 68 F. Supp. $2 \mathrm{~d} 4$ (D. Mass. 1999) (not a single White defendant prosecuted in federal court for crack cocaine charges for an entire calendar year in a region that encompassed four counties; only Black and Latino defendants were prosecuted). As this Court has recognized, just like racial discrimination in the jury 
selection process and in the decision whether to prosecute, the arbitrary and invidious use of race at any point in a criminal proceeding is fundamentally unfair and undermines any verdict, judgment or sentence.

\section{B. Overt and Subtle Racial Appeals Unjustly Taint Criminal Proceedings}

Just as allowing race to infect the determination of guilt or punishment undermines the integrity and fairness of our criminal justice system, so, too, do overt and subtle appeals to racial bias. Whether by a judge, a prosecutor, or defense counsel, an appeal to a jury based on racial prejudice poisons our system of justice. Racial appeals undermine principles of fairness and equity, and bear no rational relationship to one's guilt or to the proper determination of punishment. Notwithstanding the progress from three-fifths of a person to the Civil Rights Act of 1964 and Voting Rights Act of 1965, the passage of time and the evolution of precedent, "racial and other forms of discrimination still remain a fact of life, in the administration of justice as in our society as a whole. Perhaps today that discrimination takes a form more subtle than before. But it is not less real or pernicious." Rose v. Mitchell, 443 U.S. 545, 558-59 (1979). Though overt racial appeals are less frequent today, innuendo and insinuation are often used to arouse racial prejudice. Barring review of such invidious appeals subverts the integrity of the criminal justice system. Instead of ensuring fairness, procedural rules that bar review of claims of improper racial appeals secure injustice. 
Today, too many prosecutors improperly play to jurors' racial biases. A prosecutor may allude to a defendant's race in connection with a propensity for violence by describing that defendant in animalistic terms, degrading his or her humanity. See e.g., Bennet v. Stirling, 2016 WL 1070812 (D.S.C. Mar. 16, 2016) (prosecutor compared the Black defendant to King Kong, describing his victim, a blonde woman, to allude to her being White). Prosecutors may reference Black defendants' relationships with White women to stir up racial prejudice, and courts rightly find these insinuations irrelevant, racially charged and prejudicial. See, e.g., Moore v. Morton, 255 F.3d 95, 115 (3d Cir. 2001) (prosecutor referenced Black defendant's White wife); Bryant v. State, 25 S.W.3d 924, 925-26 (Tex. App. 2000) (prosecutor referenced Black defendant impregnating "a White girl"); Dawson v. State, 734 P.2d 221, 223 (1987) (prosecutor referenced Black defendant's irrelevant "physical relationship" with White woman); United States v. Grey, 422 F.2d 1043, 1044-45 (6th Cir. 1970) (overturning death sentence where prosecutor asked character witness whether he knew the Black defendant was "running around with a White go-go dancer"). These cloaked racial appeals do not bear on guilt or innocence, and have no relevance to appropriate punishment; rather these appeals incite racial animus for the purpose of securing conviction or a stiffer punishment.

Racial appeals, which play on the dehumanizing stereotypes discussed above, have no place in our criminal justice system, yet they are disturbingly routine. See e.g., United States $v$. Cannon, 88 F.3d 1495, 1503 (8th Cir.1996) (holding prosecutor's reference to Black defendants as "bad 
people" was a due process violation); United States $v$. Doe, 903 F.2d 16, 27-28 (D.C. Cir. 1990) (finding prosecutor's statement that "Jamaican[s][are] ... coming in and they're taking over" and use of "they" and "them" was prejudicial); McFarland v. Smith, 611 F.2d 414, 416, 419 (2d Cir. 1979) (finding prosecutor's statement that Black police officer's testimony about Black defendant was credible because it was "someone she knows and that's a member of her own race" created "a distinct risk of stirring racially prejudiced attitudes"); Withers $v$. United States, 602 F.2d 124, 125-27 (6th Cir. 1979) ("Not one white witness has been produced in this case that contradicts [the victim's] position in this case"); Miller v. North Carolina, 583 F.2d 701, 707 (4th Cir. 1978) (finding prosecutor's statement that "I argue to you that the average White woman abhors anything of this type...with a Black man" in rape case violated due process); Kelly $v$. Stone, 514 F.2d 18, 19 (9th Cir. 1975) (finding prosecutor asking jury to "[t]hink about the consequences of letting a guilty man...go free. Because maybe the next time it won't be a little Black girl from the other side of the tracks; maybe it will be somebody that you know" denied Black defendant a fair trial when taken together with other inappropriate comments); United States ex rel. Haynes v. McKendrick, $481 \mathrm{~F} .2 \mathrm{~d}$ 152, 155, 161 (2d Cir. 1973) (finding Black defendants were denied fair trial where prosecutor stated defense counsel's "experience with the people of the colored race" provided knowledge of "their weaknesses and inability to do certain things that maybe are commonplace for the ordinary person to do."); State v. Hinton, 43 S.E.2d 360, 361 (1947) (prosecutor's statement "I do not ask you to convict the defendants merely because a White man was 
killed by a negro" found to be reversible error). Conjuring racial animus in jurors serves to detract from the administration of justice, from the finding of truth, and from the fairness of a trial.

Prosecutors "may strike hard blows" but they may "not...strike foul ones. It is as much his duty to refrain from improper methods calculated to produce a wrongful conviction as it is to use every legitimate means to bring about a just one." Berger $v$. United States, 295 U.S. 78, 87 (1935). Because racial appeals so thoroughly taint the fairness of a trial, such appeals are just as illegitimate when made by defense counsel as they are when made by a prosecutor. See e.g., Kornegay v. State, 174 Ga. App. 279, 280 (1985) (finding error not harmless where defense counsel stated 'Y'all niggers 40 or 50 years ago would be lynched for something like this, but you're not under the law guilty of rape because these people are just as guilty as you are"). Racial appeals brought by any party inject racial animus into a process that should be void of bias. Indeed, any introduction of a racial appeal has an irreversible impact on the entire proceeding, jeopardizing the validity of any findings or determinations: there is no way of discerning whether the result rests on reasonable inferences made from the evidence or bias engendered through racial appeals.

\section{C. $\square \quad$ This Court Has Routinely Interpreted Procedural Rules and Bars to Permit Review of Impermissible Uses of Race}

It is "incontestable that the death penalty inflicted on one defendant is 'unusual' if it discriminates against him by reason of his race, 
religion, wealth, social position, or class, or if it is imposed under a procedure that gives room for the play of such prejudices." Furman v. Georgia, 408 U.S. 238, 242 (1972) (Douglas, J., concurring) (emphasis added). This Court's jurisprudence with respect to procedure has reflected Justice Douglas' sentiment in Furman. That is, "procedural rules...are designed to enhance the accuracy of a conviction or sentence," Montgomery $v$. Louisiana, 136 S.Ct. 718, 730 (2016), and where proceedings have been infected with racial discrimination, procedural rules cannot shield such prejudice from review.

Just last term this Court addressed exclusions of jurors because of their race and reaffirmed its unconstitutionality. See Foster v. Chatman, 578 U.S. 136 S.Ct. 737 (2016). Yet such a meritorious claim may have eluded review were it not for a favorable finding on subject matter jurisdiction. While this Court could have found that Georgia's res judicata doctrine barred review of the defendant's Batson claim, it instead chose to review the merits of the claim. Id. at 1746-47. Procedure should bend toward fairness and justice. Nearly 140 years ago in Ex Parte Virginia, 100 U.S. 339 (1879), this Court considered a procedural barrier to reviewing the merits of habeas petitions from district courts. In deciding whether this Court had jurisdiction to grant the writ, the Court held the claims should be reviewed "in favor of liberty." Id. at 337. Further, in Ford v. Georgia, 498 U.S. 411 (1991), this Court found that Georgia's implementation of procedural bars to Batson claims was impermissible. In Ford this Court could well have found Georgia's procedural bar consistent with precedent because 
the petitioner's claim had already been reviewed under the standards set out in Swain v. Alabama, 380 U.S. 202 (1965) (overruled on other grounds by Batson v. Kentucky, 476 U.S. 79 (1986)); it instead rejected application of the bar and remanded the case for consideration of the merits of the defendant's claims. Ford, 498 U.S. at 425.

Similarly, in other contexts, this Court has not hesitated to reach the merits of claims raising substantial constitutional questions notwithstanding the availability of procedural escape hatches. For example, in NFIB $v$. Sebelius, this Court held that review of the challenges to the individual mandate in the Affordable Care Act was not barred by the AntiInjunction Act. 567 U. S. (2012), 132 S. Ct. 2566, 2582-84, 2593-601 (2012). See also 26 U.S.C. § 7421(a); 26 U.S.C. $\S \S 5000(\mathrm{a})$, (g)(2). And in Knox v. SEIU, 567 U. S. (2012), 132 S. Ct. 2277 (2012), this Court rejected the defendant's mootness claim in part based on the proposition that "as long as the parties have a concrete interest, however small, in the outcome of the litigation, the case is not moot." Id. at 2288 (quoting Ellis v. Railway Clerks, 466 U.S. 435, 442 (1984). Sebelius and Knox demonstrate that where this Court confronts a profound constitutional question, whether it involves the impermissible use of race, or some other constitutional imperative, precedent and practice allow for review in close cases. Procedure may bend without breaking.

This Court has ensured review of state court decisions of federal questions by avoiding state procedural bars, unless those bars are "strictly or regularly followed." Hathorn v. Lovorn, 457 U.S. 255, 262-65 (1982) (holding state procedural bar 
inadequate and reviewing state court decision ordering election without compliance with Voting Rights Act). Where this Court has acknowledged steep procedural barriers, it has also conceived just exceptions. For example, federal habeas review of federal claims is barred where there is an adequate and independent finding of procedural default on state law ground, except where failure to review the claim would result in a fundamental miscarriage of justice. Coleman v. Thompson, 501 U.S. 722 (1991).

Mr. Buck's case is alive because of this Court's acknowledgment of steep procedural bars unjustly foreclosing review of constitutional violations. This Court recognized in Martinez v. Ryan that review of state convictions and sentences are guided by procedural "rules designed to ensure that state-court judgments are accorded the finality and respect necessary to preserve the integrity of legal proceedings within our system of federalism." 132 S.Ct. 1309, 1315 (2012). See also Trevino v. Thaler, 133 S. Ct. 1911 (2013) (extending Martinez to Texas criminal appeals). Implicit in this principle is that state sentences must be subject to review where the integrity of legal proceedings is threatened. There is no greater corruption of a sentencing proceeding than an overt claim that the defendant's race is a factor that may be considered in assessing a defendant's future dangerousness.

Procedural rules are not absolutes; they are forged in service of principles of fairness, accuracy and justice. This Court has rightly given way to substantive law where procedural rules may have barred such review, particularly where there were potential impermissible uses of race. This case 
involves a death sentence infected by overt racial appeals, a finding of future dangerousness tainted by reference to Mr. Buck's race. This Court should properly find these circumstances extraordinary and worthy of review.

\section{CONCLUSION}

For all the aforementioned reasons, the judgment of the Fifth Circuit should be reversed.

Respectfully Submitted,

Deborah N. Archer Counsel of Record Daniel A. Warshawsky New York Law School Racial Justice Project 185 West Broadway New York, NY 10013 (212) 431-2138 Deborah.Archer@nyls.edu

Aderson Bellegarde Francois Georgetown University Law Center Institute for Public Representation Civil Rights Clinic 600 New Jersey Avenue Washington D.C. 20001 (202) 661-6721

JULY 2016 